\title{
PHYLOGENETIC POSITION OF TEFENNIA SCHÜTT ET YILDIRIM, 2003 (CAENOGASTROPODA: RISSOOIDEA)
}

\author{
DUYGU CEREN ÇAĞLAN ${ }^{1}$, M. ZEKI YILDIRIM ${ }^{2}$, MAGDALENA SZAROWSKA ${ }^{3}$, ANDRZEJ FALNIOWSKI ${ }^{3}$
}

\author{
${ }^{1}$ Mehmet Akif Ersoy Üniversitesi, Fen Edebiyat Fakültesi, Biyoloji Bölümü, Burdur, Turkey \\ ${ }^{2}$ Süleyman Demirel University, Burdur Faculty of Education, 15100 Burdur, Turkey \\ (e-mail: mzekiyildirim@gmail.com) \\ ${ }^{3}$ Department of Malacology, Institute of Zoology, Jagiellonian University, Gronostajowa 9, 30-387 Kraków, \\ Poland (e-mail: andrzej.falniowski@uj.edu.pl)
}

\begin{abstract}
The phylogenetic position of Tefennia tefennica Schutt et Yildirim, 2003, an endemic snail species from southwestern Turkey, was inferred with maximum likelihood analyses of DNA sequences of mitochondrial cytochrome oxidase subunit I and nuclear 18S rRNA. Tefennia belongs to the Hydrobiidae, Sadlerianinae; its sister clade comprises Grossuana Radoman, 1973, Trichonia Radoman, 1973 and Daphniola Radoman, 1973. Shell, radula and soft parts of T. tefennica are presented.
\end{abstract}

KEY WORDS: Rissooidea, endemism, COI, 18S rRNA, radula, anatomy, phylogeny, secondary loss of receptacle

\section{INTRODUCTION}

The Hydrobiidae of Turkey are represented by the subfamilies Hydrobiinae Troschel, 1857 (2 genera); Pyrgorientalinae Radoman, 1973 (2 genera) and Sadlerianinae Radoman, 1973 (8 genera) (RADOMAN 1983, SZAROWSKA 2006, YILDIRIM et al. 2006). The monotypic genus Tefennia Schütt et Yildirim, 2003 is known from only one locality in the Burdur Province, SW. Turkey (YILDIRIM et al. 2006). In the original description it is included in the Hydrobiidae (SCHÜTT \& YILDIRIM 2003), and listed among the Orientalininae by YILDIRIM et al. (2006). The type species, Tefennia

\section{MATERIAL AND METHODS}

Material: Basspinar spring, Tefenni, Burdur, Turkey, leg. D. C. ÇAĞLAN

The snails were fixed with $80 \%$ ethanol. The shells were cleaned in an ultrasonic cleaner and photographed with a CANON EOS 50D digital camera. Three adult males and three females were dissected, using a NIKON SMZ-U stereomicroscope. The female genitalia (pallial oviduct) were examined using a MOTIC light microscope. The protoconchs and radulae were examined using a JEOL JSM-5410 scan- tefennica Schütt et Yildirim, 2003, has minute dimensions and a peculiar anatomy of female genitalia, with a bursa copulatrix in an anterior position and only one rudimentary seminal receptacle $\left(\mathrm{rs}_{2}\right)$. The aim of this paper was to establish the phylogenetic position of this interesting genus using partial sequences of the mitochondrial COI and nuclear 18S rRNA genes of T. tefennica. Additionally, the shell, radula and soft-part anatomy of this species were studied. The protoconch and radula, not described earlier, were examined using SEM.

ning electron microscope, applying the techniques described by FALNIOWSKI (1990).

DNA was extracted from foot tissue of each snail. The tissue was hydrated in TE buffer $(10 \mathrm{mM}$ TRIS-HCl pH 8.0, $1 \mathrm{mM}$ EDTA) $(3 \times 10 \mathrm{~min})$; then total genomic DNA was extracted with the SHERLOCK extracting kit (A\&A Biotechnology), and the final product was dissolved in $20 \mu \mathrm{l}$ TE buffer. The PCR reaction was performed with the following primers: LCO1490 (5'-GGTCAACAAATCATAAAGATATTGG-3') 
(FOLMER et al. 1994) and COR722b (5'-TAA ACTT CAGGGTGACCAAAAAATYA-3') (WILKE \& DAVIS 2000) for the cytochrome oxidase subunit I (COI) mitochondrial gene; SWAM18SF1 (5'-GAATGGCTCA TTAAATCAGTCGAGGTTCCTTAGATGATCCAAAT C-3') and SWAM18SR1 (5'-ATCCTCGTTAAAGGG TTTAAAGTGTACTCATTCCAATTACGGAGC-3') for the $18 \mathrm{~S}$ ribosomal RNA gene (PALUMBI 1996). The PCR conditions were as follows: COI - initial denaturation step of $4 \mathrm{~min}$ at $94^{\circ} \mathrm{C}$, followed by 35 cycles of 1 $\min$ at $94^{\circ} \mathrm{C}, 1 \mathrm{~min}$ at $55^{\circ} \mathrm{C}, 2 \mathrm{~min}$ at $72^{\circ} \mathrm{C}$, and a final extension of $4 \mathrm{~min}$ at $72^{\circ} \mathrm{C} ; 18 \mathrm{~S}$ - initial denaturation step of $4 \mathrm{~min}$ at $94^{\circ} \mathrm{C}$, followed by 40 cycles of $45 \mathrm{~s}$ at $94^{\circ} \mathrm{C}, 45 \mathrm{~s}$ at $51^{\circ} \mathrm{C}, 2 \mathrm{~min}$ at $72^{\circ} \mathrm{C}$ and, after all cycles were completed, an additional elongation step of 4 min at $72^{\circ} \mathrm{C}$ was performed. The total volume of each PCR reaction mixture was $50 \mu$ l. To check the quality of the PCR products $10 \mu \mathrm{l}$ of the PCR product was run on $1 \%$ agarose gel. The PCR products were purified using Clean-Up columns (A\&A Biotechnology) and the purified PCR products were amplified in both directions (HILLIS et al. 1996) using BigDye Terminator v3.1 (Applied Biosystems), following the manufacturer's protocol and with the primers described above. The sequencing reaction products were purified using ExTerminator Columns (A\&A Biotechnology); DNA sequences then underwent electrophoresis on an ABI Prism sequencer. All the sequences were deposited in GenBank (Table 1).

The COI sequences were aligned by eye using BioEdit 5.0.0 (HALL 1999) and edited with MACCLADE 4.05 (MADDISON \& MADDISON 2002). For 18S, an initial alignment was performed using CLUSTALX 1.82 (THOMPSON et al. 1997) and edited

Table 1. Taxa used for phylogenetic analyses, with their GenBank Accession Numbers and references

\begin{tabular}{|c|c|c|c|}
\hline Species & 18S GB\# & COI GB\# & References \\
\hline Adriohydrobia gagatinella (Küster, 1852) & AF367657 & AF317881 & WILKE \& FALNIOWSKI (2001) \\
\hline Adrioinsulana conovula (Frauenfeld, 1863) & AF367656 & AF367628 & WILKE et al. (2001) \\
\hline Agrafia wiktori Szarowska et Falniowski, 2011 & JF906758 & JF906762 & SZAROWSKA \& FALNIOWSKI (2011) \\
\hline Alzoniella finalina Giusti et Bodon, 1984 & AF367686 & AF367650 & WILKE et al. (2001) \\
\hline Anagastina zetavalis (Radoman, 1973) & EF070622 & EF070616 & SZAROWSKA (2006) \\
\hline Bithynia tentaculata (Linnaeus, 1758) & AF367675 & AF367643 & WILKE et al. (2001) \\
\hline Bythinella austriaca (Frauenfeld, 1857) & AF212917 & FJ545132 & FALNIOWSKI et al. (2009) \\
\hline Bythiospeum sp. & AF367664 & AF367634 & WILKE et al. (2001) \\
\hline Daphniola graeca Radoman, 1973 & EF070624 & EF070618 & SZAROWSKA (2006) \\
\hline Dianella thiesseana (Kobelt, 1878) & AY676125 & AY676127 & SZAROWSKA et al. (2005) \\
\hline $\begin{array}{l}\text { Graecoarganiella parnassiana (Falniowski } \\
\text { et Szarowska, 2011) }\end{array}$ & JN202341 & JN202348 & FALNIOWSKI \& SZAROWSKA (2011) \\
\hline Graziana alpestris (Frauenfeld, 1863) & AF367673 & AF367641 & WILKE et al. (2001) \\
\hline Grossuana codreanui (Grossu, 1946) & EF061916 & EF061919 & SZAROWSKA et al. (2007) \\
\hline Hauffenia tellinii (Pollonera, 1898) & AF367672 & AF367640 & WILKE et al. (2001) \\
\hline Heleobia dalmatica (Radoman, 1974) 1 & AF367661 & AF367631 & WILKE et al. (2001) \\
\hline Hydrobia acuta (Draparnaud, 1805) & AF367680 & AF278808 & WILKE \& DAVIS (2000) \\
\hline Islamia piristoma Bodon et Cianfanelli, 2001 & AF367671 & AF367639 & WILKE et al. (2001) \\
\hline Lithoglyphus naticoides (C. Pfeiffer, 1828) & AF367674 & AF367642 & WILKE et al. (2001) \\
\hline Marstoniopsis insubrica (Küster, 1853) & AF367676 & AY027813 & FALNIOWSKI \& WILKE (2001) \\
\hline Pseudamnicola lucensis (Issel, 1866) & AF367687 & AF367651 & WILKE et al. (2001) \\
\hline Pyrgula annulata (Linnaeus, 1767) & AY676124 & AY341258 & SZAROWSKA et al. (2005) \\
\hline Radomaniola callosa (Paulucci, 1881) & AF367685 & AF367649 & WILKE et al. (2001) \\
\hline Rissoa labiosa (Montagu, 1803) & AY676126 & AY676128 & SZAROWSKA et al. (2005) \\
\hline Sadleriana fluminensis (Küster, 1853) & AF367683 & AY273996 & WILKE et al. (2001) \\
\hline \multirow[t]{3}{*}{ Tefennia tefennica Schütt et Yildirim, 2003} & JX982799 & JX982802 & present study \\
\hline & JX982800 & JX982803 & present study \\
\hline & JX982801 & JX982804 & present study \\
\hline Trichonia kephalourissonia Radoman, 1973 & EF070630 & EF070619 & SZAROWSKA (2006) \\
\hline Ventrosia ventrosa (Montagu, 1803) & AF367681 & AF118335 & WILKE \& DAVIS (2000) \\
\hline
\end{tabular}


with MACCLADE. Mutational saturation for the COI dataset was examined by plotting the numbers of transitions and transversions for all the codon positions together, and for the 3rd position separately, against the percentage sequence divergence, using DAMBE 5.2.9 (XIA 2000). We also used DAMBE 5.2.9 to perform the saturation test (XIA et al. 2003). It revealed a significant degree of saturation in the third position of the sequences. In rissooids, COI approaches saturation with about $18.6 \%$ or 120 nucleotide differences (DAVIS et al. 1998), which seems to happen after ap- proximately 10 million years. However, to avoid a substantial loss of information in the case of closely related species, this position was not excluded from the dataset and it was used for the analysis. Initially, we performed phylogeny reconstruction for $18 \mathrm{~S}$ and COI data separately, using the maximum likelihood (ML) technique.

For each ML analysis, we used the best fit model of sequence evolution found by Modeltest v3.06 (POSADA \& CRANDALL 1998, POSADA 2003). The best model for each dataset was chosen using the Akaike Informa-

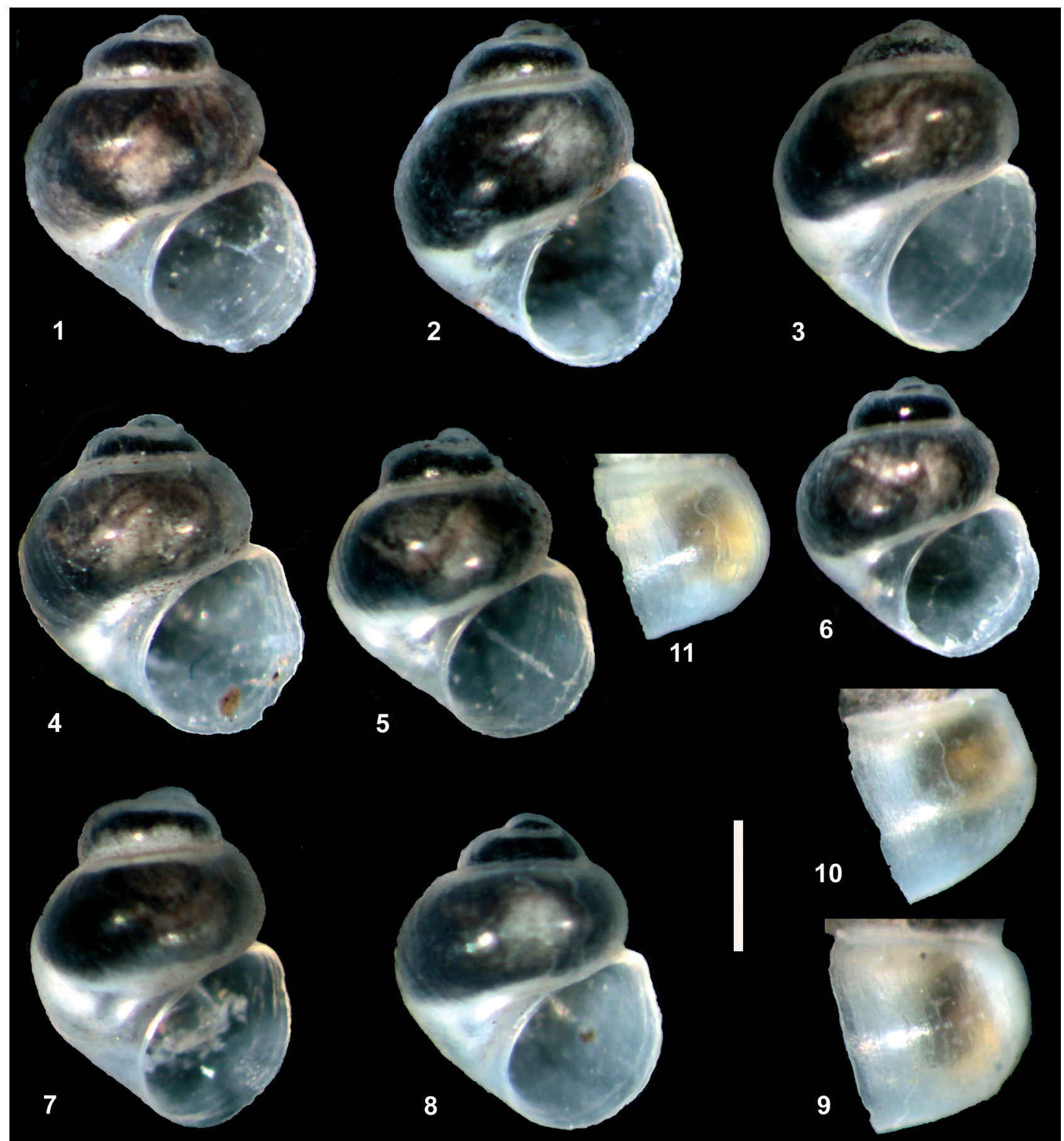

Figs 1-11. Shells of Tefennia tefennica; bar represents $500 \mu \mathrm{m}$ 
tion Criterion (AKAIKE 1974). We performed ML analyses in PAUP*4.0b10 (SWOFFORD 2002) and used a heuristic search strategy with stepwise addition of taxa, 10 random-sequence addition replicates, and tree-bisection-reconnection (TBR) branch swapping (SWOFFORD et al. 1996). Nodal support was estimated using the bootstrap (BS) approach (FELSENSTEIN 1985). Bootstrap values for ML trees were calculated using 1,000 bootstrap replicates, the "fast" heuristic search algorithm, and the same model parameters as for each ML analysis. Next, the partition homogeneity test (FARRIS et al. 1995) was performed (1,000 replicates) with PAUP*, to check whether the two genes could be analysed together. Due to its results ( $p>0.7253$ ), the maximum likelihood heuristic search was then run for the combined molecular data.

In the phylogeny reconstruction, we used GenBank sequences from 27 rissooid taxa (Table 1). Seven of these, used as an outgroup, represented the main non-hydrobiid lineages within the Rissooidea (WILKE et al. 2001); another seven taxa represented the Hydrobiinae (including "Pyrgulinae": SZAROWSKA et al. 2005). The remaining taxa were chosen to represent all the main lineages within the European Sadlerianinae (SZAROWSKA 2006).

\section{RESULTS AND DISCUSSION}

The shell of T. tefennica (Figs 1-11) corresponds to the description of the species and drawings by SCHÜTT \& YILDIRIM (2003: fig. 1). Protoconch surface malleated (Figs 12-13). Head and body pigmentation like in SCHÜTT \& YILDIRIM (2003: fig. 1). Ctenidium present, number of ctenidial lamellae 8-11. Osphra-

dium crescent-shaped. Radula (Figs 14-15) taenioglossate, central tooth formula:

$$
\frac{6-1-6}{1-1}
$$
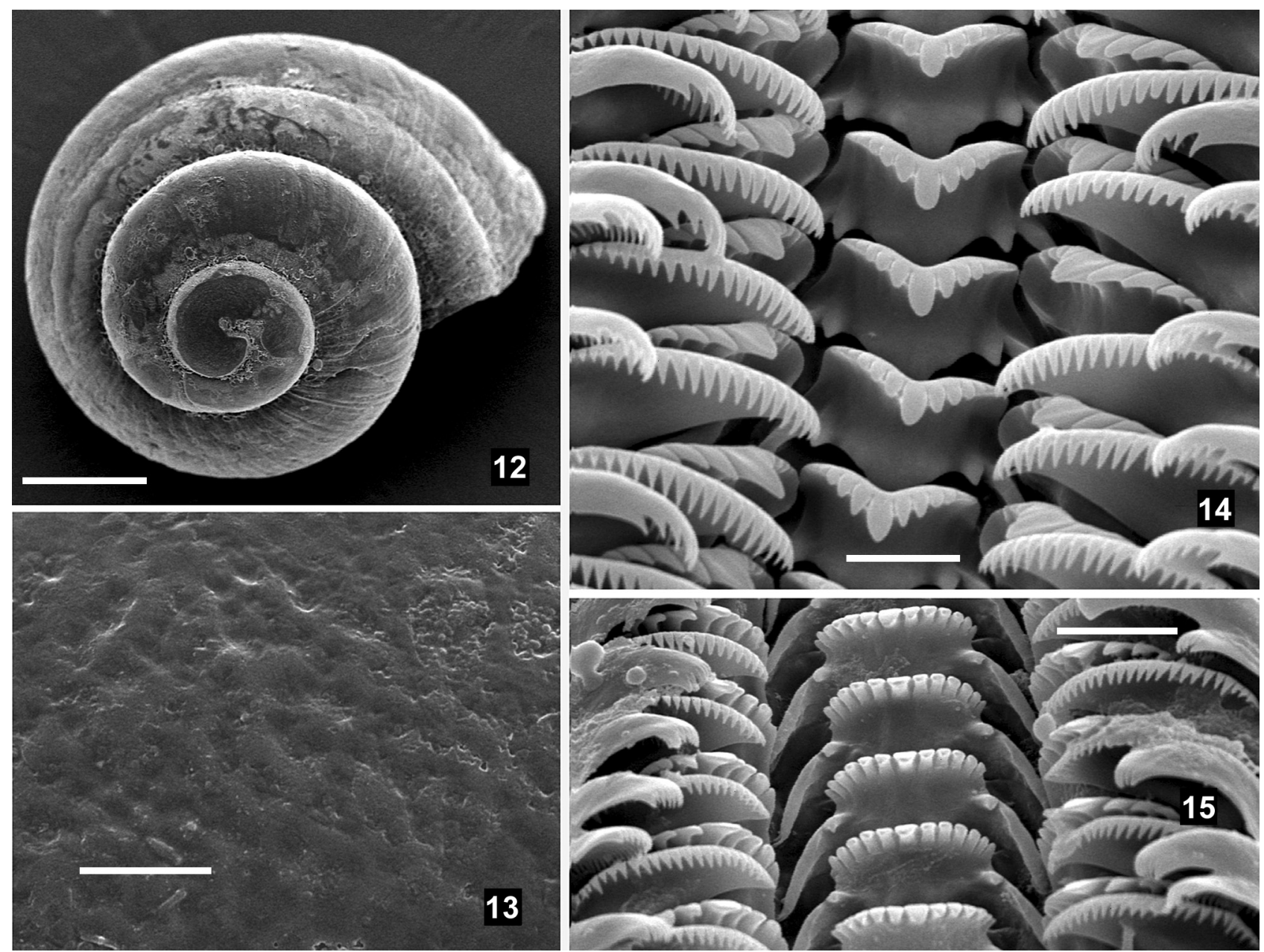

Figs 12-15. SEM pictures of shell and radula of Tefennia tefennica: 12 - shell, 13 - protoconch surface, 14-15 - radula; bars represent $250 \mu \mathrm{m}, 10 \mu \mathrm{m}, 5 \mu \mathrm{m}$ and $20 \mu \mathrm{m}$, respectively 

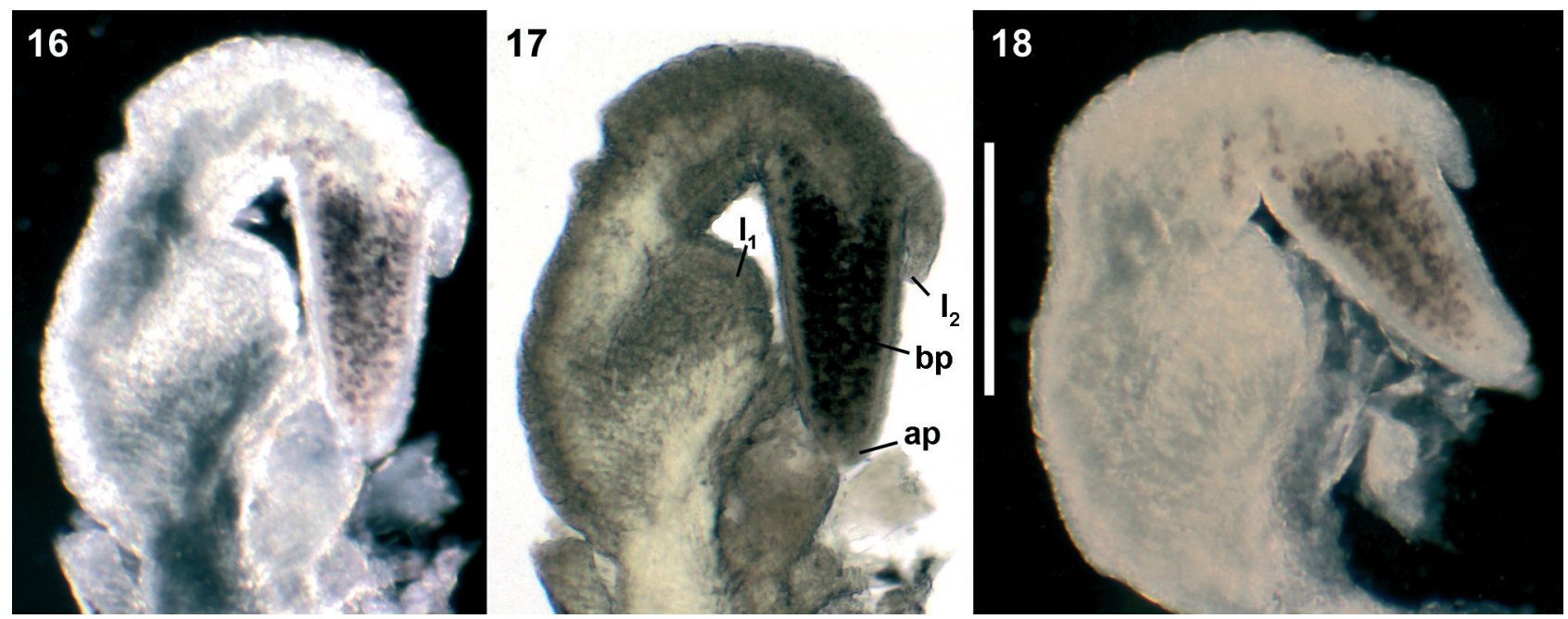

Figs 16-18. Penis of Tefennia tefennica (ap - apical papilla, bp - black pigment, 11, 12 - lobes); bar represents $100 \mu \mathrm{m}$

Lateral tooth formula: 4-14. All cusps on central and lateral teeth comparatively stout and massive. Intestine course S-shaped. Stomach without caecum.

Penis (Figs 16-18) apically pigmented black, with apical papilla and 2 lobes: one bigger in basal part and one smaller at 1/3 length distal. Female genitalia (Fig. 19) correspond to the description and drawings by SCHÜTT \& YILDIRIM (2003: fig. 1). Proximal seminal receptacle $\left(\mathrm{rs}_{2}\right)$ rudimentary and inconspicuous, yet present.

Three sequences of COI and three of $18 \mathrm{~S}$ (Table 1) were analysed for T. tefennica. For the COI sequences the Akaike Information Criterion (AIC) with ModelTest found model GTR $+\mathrm{I}+\Gamma$, with base frequencies: $\mathrm{A}=0.3356, \mathrm{C}=0.1493, \mathrm{G}=0.1434, \mathrm{~T}=0.3716$; substitution rate matrix: $[\mathrm{A}-\mathrm{C}]=0.8707,[\mathrm{~A}-\mathrm{G}]=8.1241$, $[\mathrm{A}-\mathrm{T}]=0.3577,[\mathrm{C}-\mathrm{G}]=2.7037,[\mathrm{C}-\mathrm{T}]=13.1246$, $[\mathrm{G}-\mathrm{T}]=1.0000$, proportion of invariable sites: $(I)=0.6074$, and $\Gamma$ distribution with the shape parameter $=0.3721$. For the combined data set the Akaike Information Criterion (AIC) with ModelTest found model $\mathrm{GTR}+\mathrm{I}+\Gamma$, with base frequencies: $\mathrm{A}=0.3356$, $\mathrm{C}=0.1493, \mathrm{G}=0.1434, \mathrm{~T}=0.3716$; substitution rate matrix: $[\mathrm{A}-\mathrm{C}]=0.8707,[\mathrm{~A}-\mathrm{G}]=8.1241,[\mathrm{~A}-\mathrm{T}]=0.3577$, $[\mathrm{C}-\mathrm{G}]=2.7037,[\mathrm{C}-\mathrm{T}]=13.1246,[\mathrm{G}-\mathrm{T}]=1.0000$, proportion of invariable sites: $(\mathrm{I})=0.6074$, and $\Gamma$ distribution with the shape parameter $=0.3721$.

In the COI analysis (Fig. 20) Tefennia was resolved within the Hydrobiidae Troschel, 1857, subfamily Sadlerianinae Radoman, 1977 (after SZAROWSKA 2006). Its sister clade consisted of Grossuana Radoman, 1973, Trichonia Radoman, 1973, and Daphniola Radoman, 1973. The bootstrap support for this placement was $57 \%$ (Fig. 20). In an ML tree computed for all molecular data (COI and 18S) the sister group of Tefennia was the same as in Fig. 20 but its support was higher (68\%: Fig. 21). On the other hand, the relationships between this clade (Tefennia, Daphniola, Grossuana and Trichonia) and the other genera of the Sadlerianinae in Fig. 21 were somewhat different from the corresponding relationships shown in Fig. 20. However, in both trees (Figs 20-21) the clade was placed within the Sadlerianinae. It has to be noted, however, that low values of supports may only suggest the pattern presented.

The molecularly-inferred phylogenetic relationships of Tefennia suggest that the loss of the distal receptacle $\left(\mathrm{rs}_{1}\right)$ in this genus is secondary. Within the genera included in the phylogenetic analysis in the

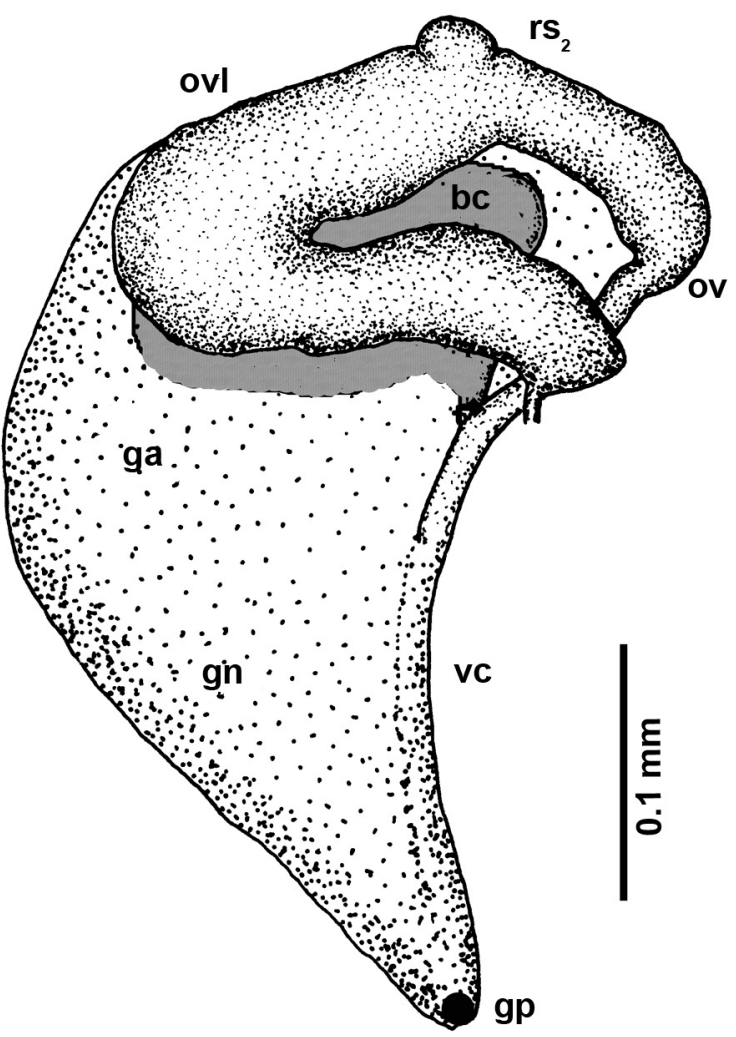

Fig. 19. Renal and pallial section of female reproductive organs of Tefennia tefennica (bc - bursa copulatrix, ga albuminoid gland, gn - nidamental gland, gp gonoporus, ov - oviduct, ovl - loop of the (renal) oviduct, $\mathrm{rs}_{2}$ - seminal receptacle, vc - ventral channel) 


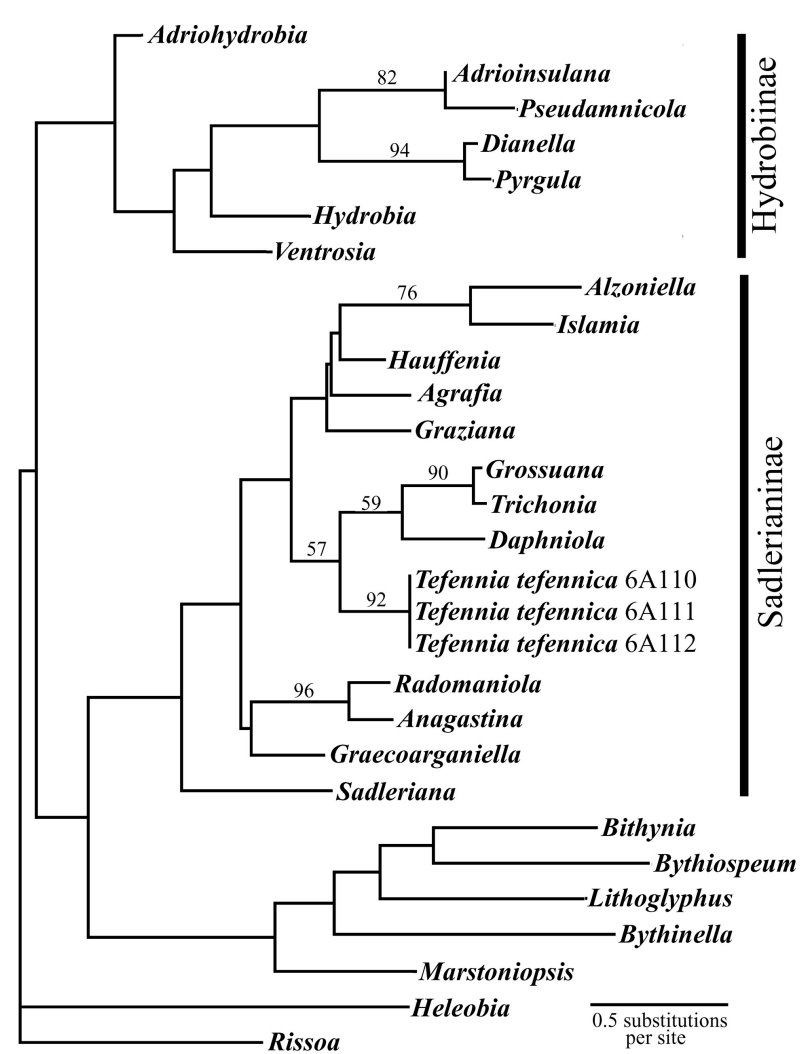

Fig. 20. ML phylogram based on COI, bootstrap supports given where $>50$

present study (Figs 20-21) a parallel loss of the distal seminal receptacle concerns Hauffenia (BoDon et al. 2001). There are other valvatiform hydrobiids that have lost their $\mathrm{rs}_{1}$ (Lyhnidia, Pseudohoratia, Strugia, Zaumia: BODON et al. 2001) but without molecular

\section{REFERENCES}

AKAIKE H. 1974. A new look at the statistical model identification. IEEE Trans. Automat. Contr. 19: 716-723. doi: 10.1109/TAC.1974.1100705

BODON M., MANGANELli G., GiUSTI F. 2001. A survey of the European valvatiform hydrobiid genera with special reference to Hauffenia Pollonera, 1898 (Gastropoda: Hydrobiidae). Malacologia 43: 103-215.

Davis G. M., Wilke T., SPOlSky C., QIU C.-P., QIU D.-C., XIA M.-Y., Zhang Y., RosenberG G. 1998. Cytochrome oxidase I-based phylogenetic relationships among the Pomatiopsidae, Hydrobiidae, Rissoidae and Truncatelidae (Gastropoda: Caenogastropoda: Rissoacea). Malacologia 40: 251-266.

FALNIOWSKI A. 1990. Anatomical characters and SEM structure of radula and shell in the species-level taxonomy of freshwater prosobranchs (Mollusca: Gastropoda: Prosobranchia): a comparative usefulness study. Folia Malacol. 4: 53-142.

FALNIOWSKI A., SZAROWSKA M. 2011. A new genus and new species of valvatiform hydrobiid (Rissooidea; Caenogastropoda) from Greece. Moll. Res. 31: 189-199.

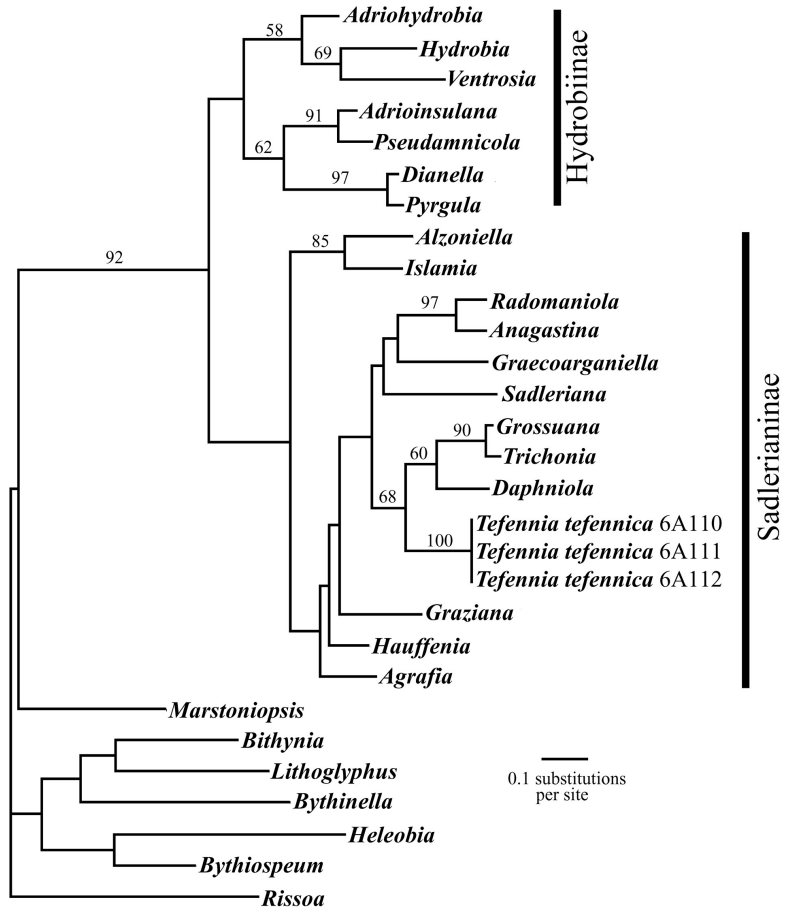

Fig. 21. ML phylogram based on COI and 18S, bootstrap supports given where $>50$

data the phylogenetic relationships of these genera are not clear.

\section{ACKNOWLEDGEMENTS}

The study was supported by a grant from the National Science Centre $(2011 / 01 / B / N Z 8 / 01721)$ to ANDRZEJ FALNIOWSKI.

FALNIOWSKI A., SZAROWSKA M., SIRBU I. 2009. Bythinella Moquin-Tandon, 1856 (Gastropoda: Rissooidea: Bythinellidae) in Romania: species richness in a glacial refugium. J. Nat. Hist. 43: 2955-2973. doi: 10.1080/0022 2930903359636

FALNIOWSKI A., WILKE T. 2001. The genus Marstoniopsis (Gastropoda: Rissooidea): intra- and intergeneric phylogenetic relationships. J. Moll. Stud. 67: 483-488. doi: $10.1093 /$ mollus /67.4.483

FARris J. S., KÄllersjÖ M., Kluge A. G., Bult C. 1995. Testing significance of incongruence. Cladistics 10: 315-319. doi: 10.1111/j.1096-0031.1994.tb00181.x

FELSENSTEIN J. 1985. Confidence limits on phylogenies: an approach using the bootstrap. Evolution 39: 783-791. doi: $10.2307 / 2408678$

FOlMER O., BlaCK M., HOEH W., LUtZ R. A., VRIJENHOEK R. C. 1994. DNA primers for amplification of mitochondrial cytochrome c oxidase subunit I from diverse metazoan invertebrates. Mol. Mar. Biol. Biotechnol. 3: 294-299. 
HALL T. A. 1999. BioEdit: a user-friendly biological sequence alignment editor and analysis program for Windows 95/98/NT. Nucleic Acids Symp. Ser. 41: 95-98.

Hillis D. M., MABle B. K., LARSON A., DAVIS S. K., ZimMER E. A. 1996. Nucleic acids IV: sequencing and cloning. In: Hillis D. M., Moritz C., Mable B. K. (eds). Molecular systematics. 2 ed. Sinauer Associates, Inc., Sunderland, Massachusetts, pp. 321-381.

MADDISON D. R., MADDISON W. P. 2002. MACCLADE. Ver. 4.05. [Computer software and manual]. Sinauer Associates Inc., Sunderland.

PALUMBI S. R. 1996. Nucleic acids II: the polymerase chain reaction. In: Hillis D. M., MORITZ C., MABLE B. K. (eds). Molecular systematics. 2 ed. Sinauer Associates Inc., Sunderland, pp. 205-247.

POSADA D. 2003. Selecting models of evolution. In: SALEMI M., VANDAMmE A.-M. (eds). The phylogenetic handbook. A practical approach to DNA and protein phylogeny. Cambridge University Press, Cambridge, pp. 256-282.

Posada D., Crandall K. A. 1998. Modeltest: testing the model of DNA substitution. Bioinformatics 14: 817-818. doi: 10.1093/bioinformatics/14.9.817

RADOMAN P. 1983. Hydrobioidea a superfamily of Prosobranchia (Gastropoda). I. Systematics. Serbian Academy of Sciences and Arts, Monographs 547, Department of Sciences 57: 1-256.

SCHÜTT H., YILDIRIM M. Z. 2003. A new freshwater snail from Turkey, resembling the genus Lyhnidia Hadžišče 1956. Arch. Moll. 132: 97-103.

SWOFFORD D. L. 2002. PAUP*-Phylogenetic analysis using parsimony (* and other methods). Ver. 4. [Computer software and manual]. Sinauer Associates Inc., Sunderland.

SwOFFORd D. L., Olsen G. J., WAdDEll P. J., Hillis D. M. 1996. Phylogenetic inference. In: HILlis D. M., MORITZ C., MABLE B. K. (eds). Molecular systematics, 2 ed., Sinauer Associates, Inc., Sunderland, pp. 407-514.

SZAROWSKA M. 2006. Molecular phylogeny, systematics and morphological character evolution in the Balkan Rissooidea (Caenogastropoda). Folia Malacol. 14: 99-168.

SZAROWSKA M., FALNIOWSKI A. 2011. An unusual, flagellum-bearing hydrobiid snail (Gastropoda: Rissooidea: Hydrobiidae) from Greece, with descriptions of a new genus and a new species. J. Nat. Hist. 45: 2231-2246. doi: 10.1080/00222933.2011.591067
SZAROWSKa M., FALNiOWSKI A., RIEDEl F., Wilke T. 2005. Phylogenetic relationships of the subfamily Pyrgulinae (Gastropoda: Caenogastropoda: Hydrobiidae) with emphasis on the genus Dianella Gude, 1913. Zootaxa 891: $1-32$.

SZARowska M., GrZmil P., FAlniowski A., SirbU I. 2007. Grossuana codreanui (Grossu, 1946) and the phylogenetic relationships of the East Balkan genus Grossuana (Radoman, 1973) (Gastropoda: Rissooidea). Hydrobiologia 579: 379-391. doi: 10.1007/s10750-006-0530-4

Thompson J. D., Gibson T. J., Plewniak F., JeANMOUgin F., HigGins D. G. 1997. The ClustalX windows interface: flexible strategies for multiple sequence alignment aided by quality analysis tools. Nucleic Acids Res. 24: 4876-4882. doi: 10.1093/nar/25.24.4876

WILKE T., DAVIS G. M. 2000. Infraspecific mitochondrial sequence diversity in Hydrobia ulvae and Hydrobia ventrosa (Hydrobiidae: Rissoacea: Gastropoda): Do their different life histories affect biogeographic patterns and gene flow? Biol. J. Linn. Soc. 70: 89-105. doi: 10.1111/j.10958312.2000.tb00202.x

Wilke T., Davis G. M., FAlniowski A., GiUsti F., BodOn M., SZAROWSKA M. 2001. Molecular systematics of Hydrobiidae (Gastropoda: Rissooidea): testing monophyly and phylogenetic relationships. Proc. Acad. Nat. Sci. Philadelphia 151: 1-21. doi: 10.1635/0097-3157(2001)151 [0001:MSOHMG]2.0.CO;2

Wilke T., FAlNiOWSKi A. 2001. The genus Adriohydrobia (Hydrobiidae: Gastropoda): polytypic species or polymorphic populations? J. Zool. Sys. Evol. Res. 39: 227-234. doi: 10.1046/j.1439-0469.2001.00171.x

XIA X. 2000. Data analysis in molecular biology and evolution. Kluwer Academic Publishers, Boston, Dordrecht \& London.

XiA X., Xie Z., SAlemi M., Chen L., WANG Y. 2003. An index of substitution saturation and its application. Mol. Phyl. Evol. 26: 1-7. doi: 10.1016/S1055-7903(02)00326-3

YILDIRIM M. Z., KOCA S. B., KEBAPÇI Ü. 2006. Supplement to the Prosobranchia (Mollusca: Gastropoda) fauna of fresh and brackish waters of Turkey. Turk. J. Zool. 30: 197-204.

Received: April 4th, 2012

Revised: May 30th, 2012

Accepted: June 9th, 2012 